\title{
Journalists' Safety and Multifaceted Censorship in Colombia: An Exploratory Study
}

\author{
Adamkolo Mohammed Ibrahim \\ Department of Mass Communication, University of Maiduguri, PMB 1069 Maiduguri, Borno State, Nigeria \\ Yennué Zárate* \\ Universidad Autónoma Metropolitana-Xochimilco, Mexico; Universidad Iberoamericana, Mexico
}

\begin{abstract}
Safety of journalists has been studied as part of freedom of expression. However, there is scarce qualitative research on Colombian regional journalists' safety. This chapter seeks to address issues surrounding journalists' safety and censorship in Colombia shedding light on triple menace: the decrease in journalistic quality, citizens' right to information and the influence on journalists' professional behavior by analysing the multifaceted press censorship from 2008 to 2017, which occurred before and after the Peace Accord between FARC guerrilla and president Juan Manuel Santos. Media ethnography and in-depth interviews were used. Employing the Bourdieu's Theory of Professional Field, the praxis, rationale and censorship of journalists during the conflict were mapped. The findings shed light on how the censorship went on during a more stable period in the conflict and how journalists were silenced and threatened.
\end{abstract}

Keywords: Safety, Journalists, Censorship, Self-censorship, Conflict, Media History, Colombia, Qualitative Research, Media Ethnography

DOI: $10.7176 / \mathrm{IAGS} / 78-05$

Publication date: December $31^{\text {st }} 2019$

\section{Introduction}

Why does researching Colombian local war journalist's mater? The research question guiding this investigation is to determine what local practices and rationales conflict journalists apply during an armed conflict regarding their safety and professionalism. By studying the world of local conflict journalists in Colombia, this chapter will examine how conflict journalists reflect on and comprehend their professional performance and their ethos, and how this might shed light on their professional experiences when reporting on war in their own country. In answer to this question, the hypothesis posited is that Colombian local conflict journalists may have a critical reflection on their praxis and professional logic to cover war in its particular violent context of a fifty-year old multifaceted war. In turn, this could illuminate journalistic praxis and ethos when covering other contemporaneous wars.

In this aggressive environment for free press and journalists, we will explore whether Colombian journalists are contributing to the weakening or strengthening of democracy during conflict. The question of professional ethics, silence, for certain reporters, is the best survival discourse. As this chapter will expose, self-censorship is the result of the impunity in the country and new threats appear with online harassment to journalists. If the assassinations of journalists are not solved (FLIP, 2011, 2018) this might help to explain or validate - to a certain degree - their silence on a regional level. Given that there are inadequacies in government security policies to protect effectively journalists in conflict and post-conflict. Yet this situation does not explain the self-censorship in bigger national media (e.g. El Tiempo, Caracol, RCN). The chapter will conclude with recommendations to address censorship in Colombia and journalists' safety in conflict.

In the following, we will analyze threats to journalists in Colombia that shed light on a triple menace: the decrease in journalistic quality, a citizen's right to information and, the influence on journalists' professional behaviour. There are three kinds of censorship: political interests, economic interests, and fear. Censorship can work in different forms linked to power, repression and discipline. Foucault (1984, p.60) explains that power does not weigh on society as a repressive form, but instead 'traverses and produces things, it induces pleasure, forms of knowledge, produces discourse' [italics added]. In Colombia, during Álvaro Uribe's government the official discourse permeated several media institutions, as the power underneath the social body, reproducing the endorsed discourse of the war on terror. As Philip Knightley asserts,

The truth is that governments wage war to win and do not greatly worry about how they do it. To them media are a menace and unless there is an actual declaration of war and they can impose censorship then they have to try to persuade and coerce the media to get on side. (Knightley, 2010, p.4)

George Orwell argued that "unpopular ideas can be silenced, and inconvenient facts kept dark, without the need for any official ban" (1972, n.p.). He pointed out subtle forms of censorship that can be immersed in media culture and journalists' professional practices. There are many academic studies focused on censorship (Curry Jansen, 1991; Green \& Karolides, 2005; Jones, 2002; Warburton, 2009), given that the history of journalism has 
always been linked with censorship, not only under authoritarian regimes but also in democratic states. Colombian journalism has different levels of censorship interlaced with government, armed groups, and media. As a result, it is easy to observe evidence of Restrepo's argument that journalist's greatest and vilest professional behaviour is clearly exposed when they are under attack by violent actors.

Curry Jansen (1991) elucidates that censorship is a form of surveillance and a mechanism that gathers intelligence that the powerful can use to increase control over ideas or individuals that threaten to disrupt the established sense or order. Self-censorship manifests as the silence that journalists might impose on themselves in defence of their lives or interests. Journalists and media are targets of the wielding of power, and Colombia is not the exception. Most interviewees lived under the pressure of armed groups but also - and sometimes disregarded - are the influences exerted by politicians, public servants and advertisement revenues, all of which might silence the press.

Censorship becomes more explicit during wartime. Given that censorship is characterized as the suppression by any strategy of information, preventing citizens from being informed. In war, information control is a frequent tactic used by all sides of the conflict with the objective of preventing the enemy from using it in its favor. Therefore, censorship and self-censorship exerted formally and informally has become a practice often used and justified (Miller, 2004, 1994).

\section{Background}

The conflict was constructed by the entangled participation of four agents: the guerrillas (FARC, ELN; since 1960s now in post conflict process), the paramilitary (consisting of many sub-groups, since 1970s, now demobilized), the drug trafficking cartels (former Medellin, Cali, Cauca Valley and Caribbean Coast cartels since 1980s), the military and the State it serves. In 2012, Colombian president Juan Manuel Santos who ruled from 2010 to 2018, together with FARC guerrilla started the peace negotiations and bilateral ceasefire. In August 24, 2016 the final agreement was reached. Yet, two months later the referendum to ratify the agreement was narrowly rejected. However, the Congress ratified it in the same year without an extra plebiscite. In 2017, the post-conflict process started with several issues, to consolidate peace, and regarding journalists' security and freedom of the press, threats, attacks and assassinations. The country is ranked 129 out of 180 countries in the 2019 World Press Freedom Index. Since 1992, 51 journalists have been murdered according to Committee to Protect Journalists (2019). Colombia continues to be one of the most dangerous countries for journalists they are intimidated by gangs of former paramilitary involved in drug-trafficking. The media's close links to 'Colombia's business empires and political class undermines their editorial independence and reinforces self-censorship (Reporters Without Borders, 2019).

Censorship increased at the peak of the drug-traffic war in Colombia in the eighties with terrorist attacks and threats that limited the freedom of expression. These were followed by paramilitary and guerrilla intimidation, which censored journalists directly. Another important factor in the censorship was the propaganda campaign articulated by former president Uribe. Any opposition to that regime was regarded suspiciously. That is also a clear form of hidden censorship, Alvaro Uribe a former president was offensive and intimidated certain journalists who strayed from the official line (e.g., Hollman Morris, Claudia Jimena Duque, Daniel Coronell, Alejandro Santos); therefore, the result within the journalist's guild was silence towards these very important, issues.

Symbolic attacks on journalism in Colombia, we can refer to the cases of Jaime Garzón ${ }^{\mathrm{i}}$ and El Espectador editor Guillermo Cano. Garzón's murder resulted in the disappearance of political critique and political humour on television (see FLIP, 2018). However, despite these crude displays of violent and direct censorship, there are many cases of formal censorship in journalism that will be analyzed in the next section. Journalists are also specifically regarded in the constitution: Article 73 states that journalistic activity will be protected to guarantee professional autonomy and freedom. Finally, Article 74 states that all people have the right to access public information except in cases established by law (Constitución Política de Colombia, 1991).

\section{Literature Review}

\subsection{Theoretical Framework}

Russell's infamous feature, The Charge of the Light Brigade, set at the Battle of Balaclava (1854), described the British army's war strategies. This report became a landmark of modern journalism (following normative journalism theory); it depicted the gruesome battle and casualties of war. As a result, the public disapproved of the war, finally lading to Lord Aberdeen's resignation. In order to avoid repetition of this incident, Sir William Codrington, British military commander in chief, established a type of censorship for future wars, including the First World War (Knightley, 2003), by limiting the information war reporters could publish. In this way, he created embedded ${ }^{\text {ii }}$ reporting to transmit previously authorized propaganda. As Martin Bell wrote a century later, "It is hard to escape the conclusion that in the absence of the independent journalism that has been driven from the field, embedded reporting is by its nature deeply and dangerously misleading" (2008, p.203). 
Contemporary examples, such as conflicts in Iraq, Afghanistan, and Northern Ireland, to name a few, can help illustrate that during war, censorship can be exerted in a more frequent manner, given that political tactics include the use of information as a tool in war (Monrow \& Thompson, 2002; Wolfsfeld, 2004; Di Giovani, 2015). In this way, governments justify their actions through a 'common good', namely the legitimization of war, via a dominant discourse (cf. Foucault). Therefore, there is an Authoritarian theory (Siebert, Peterson \& Schramm, 1956) once again operating in the core of war. Press Agenda (Agenda Setting, framing and priming) is sought to frame and subordinate to the interests of the political agenda by ignoring those of the public agenda (McCombs \& Shaw, 1972; Iyengar, 1991). Therefore, informational discourse is required to follow authoritarian principles, as well as political subordination, in order not to affront or criticize political values or war strategies. Any deviation from the official government line could lead to public reprimand (of certain journalists or media by key government personnel) or, in some cases, legal punishment for acts deemed penal felonies. In this regard, key journalism studies in Colombia (Bonilla 2012, 2007, 2002, 2000; Bonilla, Castañeda, Manrique et al., 2006) have analyzed press, violence and information. Scholars Arroyave and Barrios (2012), Barrios and Arroyave (2007), and Garcés and Arroyave (2017) have examined the sociology, autonomy and security of Colombian journalists by using a quantitative approach. Therein, qualitative research on conflict journalists is emerging in this country.

The normative line of the Liberal Theory of Journalism (Siebert, Pieterson, Schramm, 1956) states that the main function of the press is to help discover the truth and to report government misconduct. In this regard, journalists ought to be watchdogs for wrongdoing, thus contributing to the strengthening of democracy. However, not all journalists follow this ideal. Latin American media politics scholar Waisbord (2000) researched cases in some South American countries (Peru, Colombia, and Brazil) regarding investigative reporting and the reality of the 'watchdog' role. These influences, in a certain manner, the democratic life of the country's case studies. News is not only straightforward objective reporting, it is also a way of storytelling, intertwined with a journalist's professional identity. Some scholars (Bird \& Dardene, 1988) argue that journalists are professional storytellers constructing narratives for the public's understanding of reality.

Bourdieu's Field Theory shares with Foucault an understanding of language rooted in Saussure's notion that "work does not exist by itself, that is, outside relationships of interdependence which unite it to other works" (Benson \& Neveu, 2005, p.10). On another level this approach will help to develop an examination of the 'journalist as an individual' in which Bourdieu's 'Habitus' plays a key role. This position points out how different categories are constantly interacting education, social background (class), competition for 'the scoop', professional distinctions, constructions of identity, and agency (the latter can be understood as within the field, society and the media). This categorization can help to comprehensively understand the 'individual journalist' (microstructure) within their agency of the media (macrostructure) and the dynamics between the two; the institutionalized rules and the praxis might give some autonomy to the field and transform power relations (Bourdieu in Benson \& Neveu, 2005).

\subsection{Informal Censorship}

Censorship does not always involve laws and constitutional articles that dictate what to publish. It has various forms, such as interference with what journalists' report, such as gathering of information, sources or obstruction of their work. Take the intimidation of journalists for instance, or the occasional use of contempt-of-court law against the media (Article 19, UDHR,1989). Gómez (city journalist) recalls that, during Uribe's mandate, two departmental capital cities remained without journalists: Arauca and Pasto. Arauca journalists had been covering human rights abuses from armed groups when they had to flee their region. A particular case is Radio Meridiano 70 at Arauca. Paramilitaries murdered the director, Efrain Varela ${ }^{\text {iii }}$ for having revealed information about them. A year later, the paramilitaries entered the radio station and killed the director in the middle of the program. Immediately after that, two lists of targeted journalists appeared, one list from guerrillas (FARC) and another from paramilitaries (Bloque vencedores de Arauca); the two blacklists (listas negras) together named all sixteen Arauca journalists. ${ }^{\text {iv }}$ Of the eight targets on the guerrilla list and the ten on the paramilitary list, two had been already killed. The Colombian Freedom of Press Foundation (FLIP) organized an emergency operative to send a plane to bring all the journalists to Bogotá. However, Varela's assassination changed journalism in the regionv That murder was clearly directed to produce silence among journalists, and it achieved its aim. The direct or indirect threats made by guerrillas or the paramilitary have affected journalists' performance, and their freedom to inform. As Reporters Without Borders (2010) indicates

The constant monitoring by the Armed forces of the information published in local media, as well as the multiple complaints towards journalists regarding their [paramilitary, guerrilla] satisfaction or dissatisfaction of news content have become both hidden and direct pressures on the media. Today in Arauca, almost all news has as a single source: the military. (n.p.)

Examples of self-censorship as a result of fear and threats include Carmen Rosa Pabón, one of the journalists threatened by FARC, and the director of the news program La voz del Cinacure, an adjunct of 
Caracol Radio. Pabón fled the region, and when the journalist returned, she radically changed the news program's content; at present, it only broadcasts official news releases and light information, according to Reporters Without Borders (2010).

\subsection{Program to Protect Journalists}

In 2000, Colombian government approved the decree 1592, which created the Program to Protect Journalists and Media Professionals (Programa de Protección a Periodistas y Comunicadores Sociales) which implements security measures to protect journalists in violent zones and dangerous missions. Therein, journalists were acknowledged as a vulnerable professional group. The decree also established the Committee of Regulation and Risk Evaluation (Comité de Reglamentación y Evaluación de Riesgos, CRER), which examines the veracity of cases and suggests and approves protection guidelines. The members are the vice-chancellor, the governmental human rights director, a delegate of the Security Administration Department (Departamento Administrativo de Seguridad, DAS) and NGOs (Media for Peace, Freedom of the Press Foundation, Journalists Associations, among others), all of whom met monthly. This program is crucial, since the government and non-governmental organizations regulate the institutional protection to journalists.

The program started with 14 journalists in 2000. Two years later, 168 journalists were under this program. According to the Colombian Home Office Report (2009) on Freedom of Expression, by 2009 this number had decreased to 129 however by 2017 it had increased to 144 journalists (FLIP, 2017). The most recent Freedom of Expression report 2018 (FLIP, 2018, p.9) revealed 477 attacks to the press, 167 more than in 2017 (53\% increase) and $120 \%$ from 2016 . Threat is the most frequent, followed by harassment - including psychological torture and gender-based attacks. In a post-conflict situation, the threats have increased exponentially.

According to NGO reports (FLIP, 2018, 2017, 2012, 2009, 2008) and this research's data, journalists in this country shows fear to exercise their rights. The censorship manifests mainly indirectly. For instance, the freedom of the press organization (FLIP, 2008) expressed their concern that high-ranked public officials, such as former president Álvaro Uribe, reprimanded journalists on their war reporting. This hostile rhetoric serves to publicly stigmatize journalists and put them at risk of violence (Freedom House, 2009). According to FLIP (2018) report, politicians, particularly at a local level, frequently denounce journalists. Even though the government provides physical protection (bodyguards) to journalists this protection is not accompanied by political protection. President Uribe's accusations towards certain journalists increase their vulnerability.

Hollman Morris, as a journalist, reported the liberation of four hostages at a clandestine camp of FARC in the department of Caquetá. On February 3, 2009, the former President of Colombia, Álvaro Uribe, stated in a news conference that Morris (OEA-IACHR, 2009), "shielded himself through his condition as a journalist to be a permissive accomplice of terrorism, [...], one thing are those friends of terrorism who act as journalists, and another thing altogether are journalists". In addition, the former head of state added that Morris "took advantage of his situation as a journalist [...] and he held a terrorist party at an alternate place from that where the soldiers and the police were released".

The UN and OAE (Organization of American States) rapporteurs of freedom of expression, La Rue and Botero (2009), stated that they did not have knowledge of any evidence that tied the journalists to criminal activities. What is more, La Rue and Botero expressed their concerns regarding the statement made by highranking government officials against journalists who are critical of the government. Uribe's statement (on Morris) "increased the risks to life and personal integrity of journalists and human rights defenders, and that generated an effect of intimidation and self-censorship among social communicators in Colombia" (OEA, 2009).

In this regard, to mark a journalist as a 'terrorist collaborator' or simply as a 'guerrilla collaborator' (colaborador de la guerrilla), without any legal evidence of such link is a clear example of the Colombian State's failure to guarantee and respect basic constitutional rights. The State attempted to slanderously criminalize these reporters without appropriate verification of the facts, and as a result this accusation created media turmoil.

Investigative journalism in Colombia is limited in the mainstream press; however, Semana and the closed Cambio newsweeklies had research units. For instance, Semana has uncovered critical issues like the Paramilitary and Politics 'Parapolitica' scandal. In addition, newspapers such as El Espectador and El Tiempo have their investigative units. Muckraking journalists from mainstream and alternative media, reporting on topics such as conflict, human rights, politics, the paramilitary and drug trafficking can face intimidation and threats from different sources (i.e., Gómez, Morris, Cano, and Santos).

As we have seen, these statistics support the view put forward above by presenting data on the high levels of intimidation and aggression faced by Colombian journalists in their work. The diagrams are also intended to facilitate a clearer understanding of the hostile context within which journalists live on an everyday basis. 
journalists to exhibit self-control. There are diverse threats to journalists that are multifaceted, for instance from 2010 to 2018 the main sources were unknown followed by public servants and public forces (FLIP, 2018, 2017, 2016, 2014, 2010).

In November 1999, media representatives signed the Colombian 'Media Discretion Accord' (see Table 1), which was an agreement regarding the broadcast of violence. Given the criticized media coverage of the conflict and aiming to reach higher quality standards regarding the coverage of violence, media academics from the Media Department of Colombia's Universidad de la Sabana proposed the framework of the 'Acuerdo por la Discreción' (Discretion Accord). Thirty-two directors of the most influential media outlets in the country agreed and signed the accord in 1999. This agreement, conceived during the violent environment that dominated Colombia at the end of the 1990s, aimed for a higher quality of coverage of the conflict as well as greater responsibility regarding the broadcasting of violence and violent situations, and peace negotiations. It is important to note that the agreement did not intend to undermine the war on drugs nor any of the actors in the armed conflict, but only to decrease the apology for violence portrayed by the media.

This was an effort at self-regulation to control news of extreme violence. However, one can argue that this was another case of censorship -is subtler and more institutionalized one- and limitation of the freedom of expression. The theoretical framework of the accord was based on the Social Responsibility Theory, developed by the Hutchins Commission regarding better professional practices and better information quality to set the basis of a journalistic renovation. The main point was that the press should acquire, in a symbolic manner, responsibility to society through an implicit 'contract'. It should be acknowledged that the initiative came from academia and the media, not from the government.

Table 1. Table 1: The Discretion Accord (Acuerdo de Discreción)

\begin{tabular}{|c|c|}
\hline S/No & \\
\hline 1 & mmunal well-being. \\
\hline 2 & \\
\hline 3 & \\
\hline 4 & \\
\hline 5 & \\
\hline \multirow{2}{*}{\multicolumn{2}{|c|}{$\begin{array}{l}\text { Aida Luz Herrera, Director Cadena Noticias radio Net; Ana Mercedes Gómez, Director El Colombiano } \\
\text { Newspaper; Andrés Botero Molina, Director Radio Ecos } 1360 \text { of Pereira; Aura Isabel Olano, Director El Liberal } \\
\text { newspaper, Cecilia Orozco, Director Noticiero de las 7; Daniel Coronel, Director Noticias Canal RCN; Darío } \\
\text { Arizmendi, Director Noticias Caracol Radio; Daissy Cañón, Director Noticiero } 24 \text { Horas; Diana Calderón, } \\
\text { Director Informativo } 24 \text { Horas; Eduardo Durán Gómez, Codirector Vanguardia Liberal Newspaper; Enrique } \\
\text { Santos, Codirector El Tiempo Newspaper; Felipe Zuleta, Director Noticiero Hora Cero; Félix de Bedout, } \\
\text { Director NTC Noticias; Francisco Javier Díaz, Director TV Hoy y NCA newscast; Gerardo Páez, Director Cadena } \\
\text { Melodía; Guillermo Gaviria, Director Periódico El Mundo; Jairo Gómez, Director Noticiero Uninoticias; Jairo } \\
\text { Pulgarín, Director de Noticias Radio Santafé; Javier Ayala, Director Noticiero En Vivo 9:30; Jhon Dider } \\
\text { Rodríguez, Director Noticias Colmando Radio; Jorge Uriel Hurtado, Director La Tarde Newspaper; Juan Carlos } \\
\text { Pérez, Director Noticias Todelar Radio; Juan B. Fernández, Director El Heraldo Newspaper; Juan Gossaín, } \\
\text { Director Noticias RCN Radio; Juan Guillermo Ríos, Director Noticias Radio Melodía; Juan Lozano, Director } \\
\text { Noticias Canal City Tv ; María Teresa Ronderos, Magazine Director La Nota Económica; Mauricio Vargas, } \\
\text { Director Cambio Magazine; Max Duque Rengifo, Director Diario del Huila; Lays Vargas, Director Noticiero } \\
\text { Hora } 13 \text { de Tele-Antioquia; Rafael Santos, Codirector El Tiempo Newswpaper; Ricardo Santamaría, Director } \\
\text { Noticiero CMI; Rafael Vergara, Director Cadena Radial Súper; Sebastián Hiller, Codirector Vanguardia Liberal } \\
\text { Newspaper; Yamid Amat, Director Noticias Canal Caracol; Miguel Silva, Director Semana Magazine. }\end{array}$}} \\
\hline & \\
\hline \multicolumn{2}{|c|}{ Source: Bogotá, November 4th, 1999. [Author's translation] } \\
\hline \multicolumn{2}{|r|}{$\begin{array}{l}\text { The accord aimed to improve language, increase respect for victims and families, avoid sensational (yellow) } \\
\text { journalism, verify facts, and contextualize information, but above all to inform responsibly. In a study conducted } \\
\text { by the media observatory of Universidad de la Sabana (see Velázquez \& Gutiérrez, 2001; Universidad de la } \\
\text { Sabana, 2010, 2001), researchers interviewed media directors from across the country regarding freedom of } \\
\text { expression, the peace process, and the discretion accord in order to assess the effectiveness of the accord. }\end{array}$} \\
\hline
\end{tabular}




\subsection{Threats: The Safety and Phone Tapping of Journalists}

The Colombian State has shown its inability to guarantee safety to practice journalism, particularly in certain regions, and its failure to punish crimes against journalists. The government has shown inadequate concern for the reputation or security of journalists. On one hand, the government protects journalists through the statefunded program of journalistic protection, which provides bodyguards and armoured cars to protect those under threat. On the other hand, the president and government officials (DAS) target journalists in national declarations, discrediting their work and value, as well as engaging in phone tapping and hacking, a scandal that will be analyzed in the following section. Any protection is useless if the president and government officials can accuse you of being a journalist for terrorist groups or a guerrilla supporter. The libel and stereotyping that political institutions can hang on a reporter are great and bring immense negative consequences. The effect of this declaration was extensive and harmful for the reporter's reputation, since it was made on national television following the internationally famous hostage release of Ingrid Betancourt and other FARC prisoners. The president admitted his guilt, saying that it was a mistake to point to him as guerrilla collaborator, and the government later issued a press release acknowledging the mistake. However, that statement, coming from the president on a national level, put this journalist in the spotlight, and consequently, threats increased (Montaña, González, \& Ariza, 2015).

In this regard, the United Nations and the Organization of American States (OAS) have urged the Colombian government not to stigmatize journalists. The UN Rapporteur of Freedom of Expression, Frank La Rue (IACHR, 2010), expressed serious concern regarding this stigmatization of journalists in Colombia, particularly regarding Hollman Morris. This journalist works under the OAS (Organization of American States) preventive measures, and thus the Colombian state is obliged to protect him. Since 2005, he has been assigned bodyguards. Morris (City Journalist) comments: "In 2000, threats made me flee the country with my family. When I came back, I was threatened again with funeral wreaths in 2005 . Uribe pointed to me on all the radio stations as having links with guerrillas".

Another form of stigmatization is legal harassment, such as the belittlement and slander of witnesses. In this vein, legal harassment also includes judiciary orders to testify in court and violate their right to professional secrecy as well as criminal libel and legal responsibility lawsuits towards journalists. Some 12 journalists (columnists) have been charged, including Alfredo Molano columnist of El Espectador and María Jimena Duzán of El Tiempo.

Through judiciary actions, opinion journalism has been restricted, and freedom of the press has been attacked. An emblematic case is that of Alfredo Molano, a veteran journalist and sociologist, who was sued for libel due to one of his weekly articles in El Espectador, titled 'Araujos et al.' published in February 2007. In this article he criticized the corruption of economic and political power among certain Caribbean families in Colombia. The Araujo de Valledupar family sued Molano for slander. The process lasted three long years, until the court found him innocent. This is a clear example of the type of persecution that journalists may face. Therefore, in sensitive cases, journalists often prefer to leak the story to bigger national media than to break the story by themselves.

In 2009, the systematic espionage of journalists devized by high-ranking officials from the Colombian government's Administrative Department of Security (Departamento Administrativo de Seguridad, DAS) was exposed. Since 2003, government officials had intercepted and recorded emails and telephone conversations and had followed certain journalists. In consequence, sources became more hesitant to talk to journalists, because they are no longer guaranteed protection, and not even the journalists themselves are immune. In the phone tapping (chuzadas) scandal, government was exposed-for either covering up or instructing-the illegal telephone interceptions and by following journalists and human right defenders, orchestrated by its intelligence department, the DAS.

A delegation of Reporters Without Borders (RWB) visited Colombia together with AMARC (the World Association of Community Radios) in 2010. The committee researched illegal interceptions of intellectuals and journalists who were critical of the establishment during Uribe's government. Among those investigated were 16 journalists and several media (Reporters Without Borders, 2010). The government spied on journalists, human rights defenders, NGOs, politicians from opposition parties, and top judges -they even spied on themselves- and all these actions were ordered by Uribe during his term as president. 'Puerto ASIS' was the name given to the intelligence gathered on Hollman Felipe Morris Rincón and his Contravía crew, Daniel Coronell (Noticias UNO), Félix de Bedut ( $\mathrm{L} a \mathrm{~W}$ Radio), their families, and work team. According to the Committee to Protect Journalists (2010), the strategy was to primarily gather information in order to start a smear campaign on an international level through press releases, to include them in a FARC guerrilla video, and to suspend their visas.

\section{Material and Methods}

The methodological approach taken in this study is qualitative research, based on media ethnography particularly 'ethnography of journalists' (Boyer \& Hannerz, 2006) and so uses anthropological inquiry into media (Hannerz, 
2004; Pedelty, 1995), media anthropology (Askew \& Wilk, 2002). The main purpose of this tool was focused on collecting data on the dynamics of the research subjects (local/regional journalists). Therefore, in-depth face-toface interviews were carried out with local journalists, editors and NGO professionals. The data was collected over a period of six months in various Colombian regions. The research subjects have Colombian origin, mainly journalists who are linked to conflict reporting areas. The rationale for choosing these regions is that the selected zones have important journalistic activity and have been directly affected by the conflict, either paramilitary and/or guerrilla. Respondents had been covering this theme for several years.

To keep the scope of this research as researchable as possible, 64 journalists from both the regions and main cities were interviewed in-depth. The study included mainly 26 local conflict journalists from the regions and conflict journalists from Bogotá, nine newspaper editors, and eight NGO personnel. The places were mainly Bogotá, Cundinamarca, the Caribbean region (Barranquilla, Cartagena, Bolívar, Sincelejo), and the Pacific region (Antioquia, Santander). The rationale for choosing these regions is that the selected zones have important journalistic activity and have been directly affected by the conflict. The age of respondents ranged from 24 to 60 years. The quantity of the research subjects is to have a broad qualitative sample of the journalists' situation.

The methodology of media ethnography, in-depth interviews to local, metropolitan journalists and editors will help to comprehend the praxis and rationale of journalists. These individuals are part of a small group of journalists that report conflict and are an interpretative and knowledge-production community. This group is characterized by its unity, solidarity, and its members' specialized knowledge in covering conflict. The interview (e.g., Bell, 1992; Frankfort-Nachmias \& Nachmias, 1992; Wimmer \& Dominick, 1997) semi-structured in-depth interviews in order to examine journalists' insights, narratives and their vision of their professionalism, and on their role in war. A question guide (semi-structured interview) based on reactive to its professional behaviour was used. Interviews were held in their media and outside their workplaces, on average one- to four-hour interview was the median.

\section{Solutions and Recommendations}

5.1 Results and Discussions

Self-censorship is subtle. It is the systematic omission of information that reporters or media inflict on themselves in order to secure their lives and political and economic interests. This practice is hardly ever acknowledged, and in this case, for example, it was confessed in the light of a research interview; always asserted with a hint of apologetic guilt and embarrassment. Orwell (in Brevini, 2010) identified the most terrifying kind of censorship: the kind that you practice on yourself and that you even embrace. Molano (2008) asserts that the paranoia created by a regime that imposes the Manichaeism makes self-censorship a way of life, a manner of speaking and writing. "The word loses its strength. Adulation wins, and criticism loses (...) the enemy is within, it becomes part of its sight and eventually of its word". Consequently, in this study case, selfcensorship in warfare, is a survival device.

In this regard, $80 \%$ of journalists interviewed in this research agreed that self-censorship has become a synonym for self-protection, as journalists pled guilty to this practice for their own safety. Social environment and the guild's situation have clearly influenced their practices, as they recall having omitted certain news or scopes about other colleagues' experiences or incidents that had occurred to them. In some regions, selfcensorship has become socially accepted. Impunity is another issue that was persistently guiding their professional work; the government's weak approach to implementing justice to solve hostilities against their colleagues has affected their professional judgement to avoid the same issue. "Self- censorship is that Colombian journalists are no longer going to the conflict zones, since the government has pointed to journalists that wander these zones as "linked to terrorism." (Morris, a city journalist)

Fear is the fundamental core of self-censorship among Colombian journalists. Fear of losing their job or losing their life. As this reporter puts it bluntly: "I regret to admit that I censor myself because I'm afraid to lose everything; my employment, my professional strength, my family... it is my way to stay alive..." (Anonymous B1, Regional journalist). In this regard, the United Nations High Commissioner for Refugees, in the Colombia report (2005) stated that self-censorship and intimidation has brought forward three issues. Firstly, it has stopped journalists reporting in certain places about specific news. Secondly, reports are based on official numbers or statements, and some facts that are considered dangerous are omitted from reporting. Thirdly, the report registered that many journalists abandoned their line of work.

Regarding their helplessness, journalists concurs, "To have a bodyguard in Bogotá can certainly help you. A bodyguard in rural areas, in a conflict zone, is useless." (Sierra, a city journalist). Another journalist expresses it thus: "Bodyguards, armoured cars, bullet-proof jackets, police patrols of our homes, office reinforcement in certain cases... there are thirty-four of us journalists who live this way, otherwise we could be killed." (Gómez, a city journalist). Another journalist states,

To live with the fear that you can be killed anytime... it's difficult. This is true mostly in small villages such as Santa Marta [Pacific Coast] where everybody knows everyone, and even though you don't sign your piece, 
they'll know who wrote it. (Beleño, a local journalist)

To monitor self-censorship is a complex endeavor, as the nature of personal censorship can be caused by various factors. However, the media outlet where journalists work can also be a catalyzer of self-censorship practices. Scholars (Reyes, 2007) claim that self-censorship takes place in two places, firstly as pre-censorship (journalist self-censored) and post-censorship (media censorship). Journalists in certain cases have decided to avoid pressing issues in their region, citing various reasons: self-protection, economic and political pressure, or working strains. Consequently, as observed and corroborated with colleagues, this is not open censorship, but it underlies institutions, editors, and journalists. This situation becomes more frequent in regions of conflict. Journalists' fear amidst the armed conflict is exposed through these practices. Therefore, the silence and disregard of certain information are not only a last resource but also a mode of survival.

A reporter in Buenaventura (Valle), in the Pacific area, recalls that on April 19, 2008, twelve young footballers were killed. Local journalists found out rapidly that the paramilitaries had pointed out two players as being linked to FARC. To contextualize, many journalists had been murdered in the area; this is one of the most affected regions in the conflict. "All the neighborhood knew what happened, but we couldn't publish it because of the fear [italics added]." (Vides, a local journalist)

Local journalist Vides is an example of a reporter who challenged the constraints of social censure through his feature reports "Massive detentions" at Montes de María - northern Sucre and Bolivar regions. When former president Álvaro Uribe started his term in office, he instituted the 'democratic security' policy, which was a strategy to attack illegal groups. FARC (group 35, 37) and ELN guerrillas operated in Montes de María. In 1993, 156 were detained by military and police forces; among the detainees were peasants and tobacco workers who were presented as guerrilla supporters without proof. These detentions caused impoverishment to several families in the region, yet again the feature was under-reported. A few years later, threats followed his work,

When I was a journalist for regional Radio Caracol of Sincelejo, in 1996 I was threatened, and I had to flee from the zone for a year. I went to work at a TV news channel for two months. When I came back, I was threatened again, and I had to run away once more. Since then, I've been threatened constantly. I haven't stopped doing journalism, but I've taken some precautions such as self-censorship. (Vides, a local journalist)

After my exile in 2013, I had a tough experience. When you come back, and you have access to information, many times I decide to not work on the subject, I send the information to Bogota. I don't want to be threatened again, for me and especially for my family. (Avendaño, local journalist)

Another journalist concurs,

The government's line in 2010 stated that besides the conflict, Colombia was under a terrorist threat, consequently media should be part of the government's propaganda line. I crossed that line, but I believe that I'm a minority and the majority of media has bought that argument of 'united against the war on terror (...) [I]nformation here, mainly political, is part of government's news agenda, such as RCN and El Tiempo. The journalist does not consider its critical role, but its role as an apologist of a critical government. The president has made false accusations through its media; RCN, to attack my credibility and that of the director of TV program Noticias Uno. (Gómez, a city journalist)

Self-censorship is not a uniquely Colombian phenomenon; it happens even in societies with the most plural media (Wolton, 1992). A survey of North American journalists by the Pew Centre and Columbia Journalism Review (2000) showed that $40 \%$ of professionals practice self-censorship. Local journalists face many challenges, and about $32 \%$ of local reporters acknowledged that they have softened the tone of a news story at the request of their news organizations. Although this is a case from United States, it shows similarities among the types of censorship that local journalists face; even in a country without conflict and with stability, journalists might be required to censor their work. "At the present, assassinations of journalists have diminished, but that doesn't mean that there is more information, or that freedom of expression is better, rather that the journalists have self-censored. In this situation, there are less threats but there is less information." (Cortés, an NGO director).

In this regard, journalists covering conflicts face various threats and their work is produced as if they were observed. Beleño (local journalist) says, "Bochinche (the concept that everything is known but at the same time not known) is very common, everyone knows what is happening, but it is never published, you never see a word of it in the newspaper." On self-censorship and reporting on paramilitary issues (at the Colombian coast), a journalist says,

In 2002, the year with the most paramilitary activity, everyone knew who they were [the paramilitary], but there was no way that the newspapers would publish it. This was true of all regional newspapers on the Caribbean coast: El Meridiano of Cordoba and Sucre and Vanguardia Liberal. (Beleño, a local journalist)

There is a hidden censorship among journalists, examined in this case from the Atlantic Coast. They apparently knew that the paramilitary was operating in their region; however, if they had reported the issue, they would have likely been disappeared and threatened. The situation is even harder on a more local level, for example in small villages such as Santa Marta (Atlantic Coast), "the entire city knows that you work in the 
newspaper, and report on crime. Since there are not many of us, people know who was enquiring about certain news" (Ramírez, a local journalist). In this regard, there is a news agenda with several omissions, citizens learn news through bochinche and rumours, and street gossip. As a result, controversial yet important information is absent, at the cost of the protection of journalists' lives (or work). This concept of bochinche alludes to a culture of silence regarding certain information-as a consensual behaviour immersed in a culture that is either permissive of/or unable to recognize transgressions of freedom of expression. This finding concurs with Arroyave and Blanco's (2005) research on censorship with drug-trafficking and armed actors.

The paramilitary demobilization has created several risks and hazardous topics whereby journalists are confronted with a minefield of what to report on and what to avoid. In the 2007 FLIP report, the organization documented the intimidation that journalists faced when covering the judicial hearings of demobilized paramilitaries from the AUC (United Self-Defence Forces) in Medellin, Antioquia. Their reporting was recorded and documented for unknown purposes. Additionally, they received messages of intimidation in relation to interviews recorded outside the venue of the hearings (FLIP, 2008, p.64). This resulted in journalist's selfcensorship and inhibition, and the result was bochinche as already noted. In addition, it intimidated the victims and removed them from the process (in which they could attend the hearings and ask questions regarding disappearances), thus preventing them from the possibility from attaining information about their missing relatives

Colombia's conflict merges three stages of this phenomenon: pre-conflict, conflict and post-conflict processes. The first one is the origin -as we have seen in the literature review, the guerrilla movements- the second the armed confrontations, and the third is non-violent solutions such as reconciliation and demobilization. We will focus now on the latter, the coverage of demobilization process (post-conflict). This stage was based on the disarmament of paramilitary groups through Colombia's Justice and Peace Law (Law 975) which was approved by the Colombian Congress on June 21, 2006 and ratified by the government in July of the same year. However, this process was focused in praxis on paramilitary fighters, who have been responsible for most of the massacres of civilians, together with disappearances and torture of civilians and guerrilla people (cf. Amnesty International, 2005). Most of the paramilitary hearings took place on the Atlantic Coast (Barranquilla) and were open to the media.

Before, much information was not published because of fear of targeting by subversives, but now it has changed. In Sucre we send our information to newscasts and colleagues at national newspapers, once they publish it, we pretend to do the follow up, but it is our work. There are many informations [sic] that have come up [from national press] but we're afraid to publish it, so we take the news from Colprensa, even though we are the ones who sent it. (Anonymous local journalist)

The Freedom of Press Foundation (2007) pursued an exercise with journalists from the Atlantic Coast which identified how the paramilitary themes -even during the demobilization process - are still causing intimidation and self-censorship. The topics that presented highest risk were 'how many groups continue operating in the region'; also, the number of possessions they have handed in as a requirement to appease the peace and justice law. Other hazardous topics concerned the number of victims, the clandestine burials, and minors handed in within their state. The intimidations of the paramilitary groups are still notorious in the paramilitary trials (versiones libres, 'free versions') and their relationship with the press.

During El Caguán peace negotiations, journalists that covered the process suffered prejudice in newsrooms. Since journalists were required to stay and live there around two to four weeks, "In the newsroom when we arrived (...) after such a long time, my co-workers told me, "“where are your [guerrilla's] rubber boots, where's your rifle? Did you bring the camouflage?"' (Castrillón, a city journalist). The reporter affirmed that although this was a joke at first, it became a grim comment and accusation from colleagues at the same newspaper. The result was a slight polarization of the newsroom between journalists and conflict journalists covering the peace talks. This not only happened in the newsroom but also within society, the journalist states that they suffered threats because of the stigma that conflict journalists carried as connected to the guerrilla, based only on the fact that they had to interview them and travel to their guerrilla bases as part of normal journalist reporting. In this regard, Morris (a city journalist) declares that,

Stigmatization is like a bomb. Where it falls it first destroys the family base, it affects your children, your wife, your family... and the explosion reaches your neighbors, the guards, colleagues, and people around you. Your social network regards you with suspicion. It's terrible for me, but it's even worse for democracy.

In recent years, threats have become the most common instrument to silence the press and to consolidate selfcensorship in certain regions (FLIP, 2017, 2007). There are many levels of threats; the most common are telephone calls, text messages, and e-mails. Intimidators have also sent funeral crown wreaths and threatening pamphlets. This can have a tremendous impact on journalists' fear, as the following journalist illustrates, "I was threatened by AUC's [paramilitary cluster] northern section (...) it was an e-mail and I believed it was meant to scare me. For that reason, I didn't write too revealing things [sic] about the paramilitary leader Jorge 40." (Beleño, a regional journalist) 
In this case, an e-mail threat to this regional journalist might have been sent out as a warning. Although the e-mail format was depersonalized, some journalists take it seriously while others choose to disregard it, according to each journalist's circumstances and conjunctures. However, the threat was still a caution that he might have been closer to crossing the line, since -according to the journalist- the article was not that revealing of the paramilitary leader. That is why this forewarning did not inject fear, although it did make the reporter reflect on his work and whether he had written something provocative. This exposes the vulnerability of the regional journalist, who works close to paramilitary hearings, and shows a small degree of self-censorship. Even if the threat was ignored, the poisonous effect of the menace kept the journalist aware by emphasizing that this armed group was following his work and movements. Research respondents agreed upon the importance of the unity of the journalist's guild to counterbalance self-censorship because a lonely journalist is more vulnerable.

\subsection{The Untouchable Topics}

According to Guerrero (2010), in Colombia these topics include paramilitary rearmament, emerging criminal gangs, the increase in violence levels post (paramilitary) demobilization process, links between armed groups and politicians (paramilitary-politicians), bonds between drug dealers and armed forces, the strengthening of drug-dealing networks and those of social control, the appropriation of lands belonging to indigenous groups, fieldworkers, and Afro-Colombian communities, displacement, and mine exploitation, among others. This coincided with some of this research interviewee's answers.

However, the majority coincides with regards to the paramilitary rearmament, the lack of reporting on conflicts, news about drug trafficking, corruption, and displacement. It can be clearly shown that ninety percent of journalists agree that the paramilitary rearmament is a disregarded issue. Since paramilitary hearings are taking place the focus is centred there, but regional journalists do not dare to become muckrakers in order to report on the well-known and documented issue of the formation of new paramilitary groups. While the demobilization process has ended, the attention has focused on other topics surrounding the conflict. The main reason given for its self-censorship is fear and lack of interest in the national news agenda.

Eighty-five per cent of interviewees concurred that news about displacement is rare, and never prominent in the media. When asked why they thought this issue was underreported, the greater part of respondents that had never reported about it, showed a slight embarrassment and argued that they lacked time and resources to travel to these areas or to track displaced people. In contrast, those who had covered it revealed a sense of accomplishment and gratification in knowing that they had done a decent job. Corruption is also absent from the news, particularly in regional media. Journalists admitted that corruption dealing with the state or the private sector is reported with less frequency. The situation becomes aggravated when the information is concerning certain groups connected with the media. This is due to commercial interests and advertising pressures, as discussed in the following section.

There is a disregard for investigative journalism within the regional press, given that resources are scarce. Additionally, the enormous workload, disregarding bank holidays and extra hours, make the task of investigative reporting an almost impossible one. This is due to the lack of time to reflect and assemble news with a more indepth analysis in order to explain it as a process. Another factor, as analyzed before in this section, editors and reporters favor non-controversial topics that might lead to any form of coercion. In the coverage of conflict, the news agenda usually focuses on the evolution of the conflict, detentions, the guerrillas, forms of control of armed actors, the military budget, child recruitment, mines, displacement, humanitarian accords, kidnapping, and the definition of combatants, among others. Post-conflict coverage includes demobilization, actors demobilized (leaders, groups, individuals), and reintegration programs.

\subsection{Future Research Directions}

The present study adopted a qualitative approach, focusing on in-depth interview and media ethnography. The data were analyzed based on critical discourse analysis. Future research should further explore focus-group discourse and non-in-depth interview approaches. It is expected that some of the weaknesses of the present methodological approach may be overcome and better findings yielded. Furthermore, future research should alternatively use the data generated in this study as a benchmark data and design a quantitative research framework to generate quantitative data that could be generalized. However, given the issues of press freedom and threat to journalists in Colombia are intricately linked to the 50-year-old infamous FARC insurgency, a longitudinal study would have been better adopted to generate trends about journalists' safety and press freedom in Colombia. Hence, future research should consider the feasibilities of conducing a longitudinal study.

\section{Conclusion}

Given that Colombian journalists are still facing threats, there is a need to address their safety and media protection. It is also necessary to combine qualitative and quantitative research on Colombian journalists to attain a comprehensive scope of the phenomena that will allow to an enhanced protection of journalists. Before 
and after the peace accords, the local journalists continue to work in unsafe conditions. There is also a need to research on Colombian journalists with a gender perspective, given that several women journalists face a double discrimination at work and therefore self-censorship, due to its gender and security inside the newsroom, as well as outside their media and sources.

The aggressions towards journalists constitute censorship as direct violence, that not only risks journalists' and work, but also society's right to information. There is a flaw in the makeup of the State that allows legal persecution of those that question or criticize the actions of public servants. This is best exemplified in the case of former Colombian president Ernesto Samper and the columnist Claudia López. The latter faced a judiciary process back in July 2006, accused of slander and defamation because the journalist questioned Samper's appointment as ambassador to France in her El Tiempo's newspaper column entitled: 'The Uribist reinsertion: From 8 thousand to 64 thousand' (El Tiempo, 2006). The jury, despite the petition of the judiciary prosecutor, absolved López. Although there is wide jurisprudence regarding freedom of expression, as presented in this chapter, Colombia needs precise measures in its legislation improve protection of journalists.

The lack of social recognition and lack of trust of certain journalists and against journalism as a professional guild in Colombia explains that issues of censorship, self-censorship, threats, stigmatization and homicide are minor concerns. Despite the symbolic hits to journalism, there is no social valuation of journalists as essential actors who report on the armed conflict and the strengthening of democracy. There is a geographical divide regarding the freedom of expression, as explained by an editor; "In Colombia there are two kinds of freedom of expression: there is one kind in Medellin, Bogotá, Barranquilla and Cali [the main cities], and the other one is that of the rest of the country [the regions]." (Sierra, a city editor). Therefore, the advances of journalists' protection are located mainly in the cities, with city journalists, given that there are major difficulties to protect regional journalists. Despite regional journalists are the most vulnerable ones they are the most relegated in society given their geographical location by living faraway the urban centres and power hubs. Additionally, before the post-conflict agreement, they were immersed in or extremely close to the armed conflict, in which the disciplinary measures of protection of journalists do not function or operate with difficulty.

In this aggressive environment for free press and journalists, the conflict has surpassed the question of professional ethics for certain journalists; self-censorship, helped to create a culture of silence of sensitive issues. As this chapter exposed, self-censorship is the result of impunity in the country. If the assassinations of journalists are not solved, this might help to explain or validate - to a certain degree - their silence on a regional level. Yet, intimidation and coercion are still a serious problem, professionals, in many cases, perform a mechanical role rather than acting as watchdogs (Waisbord, 2000).

Although this research focuses primarily on printed press, there are serious censorship issues that Colombian journalism faced in television news (Guerrero, 2010). The 'Democratic Security' as a political strategy has enlisted the media to help the correct implementation of defence of the state. During that time, former president Álvaro Uribe, has expressed on several occasions his dissatisfaction with the role of the press in the coverage of the conflict, and has called upon the media to become an ally of the government. This democratic security strategy intended to include civilians in the defence of the state, as informants or collaborators. The former president asked the press to incite the desertion of young people who have joined the guerrillas, as well as to inform the security forces about the location of guerrilla leaders who are contacted by the press for interviews (Ruiz, a magazine editor). This not only violated the press' code of ethics, which prevented journalists from disclosing their sources, including their whereabouts when dealing with armed actors: it also made it impractical for journalists to perform their job in the future since revealing their sources may open a window to threats and intimidation from the armed actors implicated.

\section{References}

Arroyave, J. \& Barrios, M. M. (2012). Journalists in Colombia. In D.H. Weaver \& L. Willmat (Eds.), The Global Journalist in the 21st Century (pp.: 400-412). Routledge: London. Retrieved from: http://perfilesla.flacso.edu.mx/index.php/perfilesla/article/view/784

Arroyave, J. \& Blanco, I. (2005). Cómo perciben los periodistas su profesión: Entre el agotamiento y la fascinación. Investigación y Desarrollo, 13(2), 364-389.

Amnesty International. (2009). Document Colombia: Fear for Safety, Hollman Morris. Amnesty International. Available from http://www.amnesty.org/en/library/asset/AMR23/007/2009/en

Article 19. (2010). Propuesta de ARTICLE 19, Para la Creación y Operación del Comité de Protección a Periodistas. Mexico City: Article 19.

Barrios, M. M. \& Arroyave, J. (2007). Perfil Sociológico de la Profesión del Periodista en Colombia: Diálogo Íntimo con el ser Humano Detrás de las Noticias. Diálogos de la Comunicación, 75. Retrieved from http://www.javeriana.edu.co/felafacs2006/mesa13/documents/barriosyarroyave.pdf

Bell, M. (1996a). In harm's way. London: Penguin.

Benson, R. \& Neveu, E. (2005). Introduction: Field theory as a Work in progress, Bourdieu and the journalistic 
field. Cambridge: Polity Press.

Bourdieu, P. (2005). Bourdieu and the journalistic field. Cambridge: Polity Press.

Bonilla, J. (2002). Periodismo, guerra y paz. Campo intelectual periodístico y agendas de la información en Colombia. Signo y Pensamiento, xxi (40), 53-71.

Bonilla, J. (2007). Las violencias en los Medios, Los Medios en las Violencias. Bogotá: Centro de Investigación Popular CINEP.

Bonilla, J. I. (2012). Periodismo, guerra y paz. Campo intelectual periodístico y agendas de la información en Colombia. Signo y Pensamiento. 21(40), 53-71.

Bonilla, J. I., Castañeda, R., Manrique, M., et al. (Eds). (2006). Prensa, conflicto armado y región: Aprendizajes del diplomado Periodismo responsable en el conflicto armado. Bogotá: Cooporación Medios Para la PazPrograma por la Paz-Pontífica Universidad Javieriana.

Brevini, B. (2010). Censorship and Orwell's Legacy: Interview with J. Seaton. Westminster Papers in Communication and Culture. 7(2), 6-11.

Curry Jansen, S. (1991). The knot that binds power and knowledge. New York: Oxford University Press.

Committee to protect Journalists, Colombia. (2019). Available from https://cpj.org/americas/colombia/

Di Giovanni, J. (2015). The rules of conflict reporting are changing. Committee to Protect Journalists Attacks on the Press 2015, 27 April. Available from https://cpj.org/x/5fea

El Espectador. (2009) Uribe insiste en que Fiscalía debe investigar a Morris. El Espectador, $11^{\text {th }}$ February. Available from http:/www.elespectador.com/noticias/politica/articulo116853-uribe-insiste-fiscalia-debeinvestigar-morris

Foucault, M. (2001). Fearless speech. New York: Semiotext.

Fundación para la Libertad de Prensa (FLIP). (2018). La Prensa Acorralada: Un juego de violentos y poderosos. Informe sobre el estado de la libertad de Prensa en Colombia 2018. FLIP Colombia. Available from https://www.flip.org.co/index.php/es/publicaciones/informes-anuales/item/2315-informe-anual-prensaacorralada-un-juego-de-violentos-y-poderosos

Fundación para la Libertad de Prensa (FLIP). (2017). Estado Depredador. Informe sobre el estado de la libertad de Prensa en Colombia 2017. FLIP Colombia. Available from https://www.flip.org.co/index.php/es/publicaciones/informes-anuales/item/2188-informe-anual-2017-unestado-depredador-de-la-libertad-de-prensa

Fundación para la Libertad de Prensa (FLIP). (2015). Paz en los titulares, miedo en la redacción. Informe de la libertad de prensa en Colombia 2016. FLIP Colombia. Available from https://www.flip.org.co/index.php/es/publicaciones/informes-anuales/item/1876-paz-en-los-titulares-miedoen-la-redaccion

Fundación para la Libertad de Prensa (FLIP). (2011). Grave amenaza contra la vida de periodista de El Espectador en Medellín. FLIP Colombia. Available from http://www.flip.org.co/alert_display/0/2178.html

Fundación para la Libertad de Prensa (FLIP). (2010). Interceptaciones y seguimientos ilegales: Grave intimidacion al periodismo Colombiano. Informe Anual Sobre el Estado de la Libertad de Prensa en Colombia. Bogotá: Fundación para la Libertad de Prensa.

Fundación para la Libertad de Prensa (FLIP). (2009). La amenaza y la estigmatización: Las intimidaciones invisibles contra la prensa. Informe sobre el estado de la Libertad de Prensa en Colombia en 2008. Bogotá: Fundación para la Libertad de Prensa.

Fundación para la Libertad de Prensa (FLIP). (2008). The Challenge of Reporting. Report on the state of the Freedom of the Press in Colombia in 2007. Bogotá: Fundación para la Libertad de Prensa.

Fundación para la Libertad de Prensa (FLIP). (2007). El desafio de informar en Colombia. Bogotá: Fundación para la Libertad de Prensa, Reporters Without Borders, United Kingdom Embassy.

Fundación para la Libertad de Prensa. (2006) Manual para el apoyo emocional al periodista. Universidad Sergio Arboleda-Resilencia Centro de Investigación y Apoyo Emocional para el Periodista, United Kingdom Embassy.

Fundación para la Libertad de Prensa (FLIP). (2006). Parámetros para el ejercicio informativo de los medios de comunicación en el marco del sistema penal acusatorio. Comisión Interinstitucional para la Implementación del Sistema Penal, USAID.

Garcés Prettel, M. \& Arroyave Cabrera, J. (2017). Riesgos de seguridad y autonomía profesional de los $\begin{array}{lllll}\text { periodistas en } \quad \text { Colombia.Perfiles } \quad \text { Latinoamericanos, } & \text { 25(49),1-19. }\end{array}$ from http://perfilesla.flacso.edu.mx/index.php/perfilesla/article/view/784

Green, J. A. \& Karolides, N. J. (2005). The Encyclopaedia of Censorship. New York: Facts on File, Inc.

Guerrero, A. (2010). País Lejano y Silenciado: Autocensura y prácticas periodísticas en el periodismo regional. Bogotá: Fundación Para la Libertad de Prensa, Corporación Medios Para la Paz.

Inter American Commission on Human Rights. (2009). The rapporteur for freedom of expression of the UN and of the OAS express their concern regarding comments made by high authorities of the Colombian 
government against journalist. Inter American Commission on Human Rights, Office of the Special $\begin{array}{lllll}\text { Rapporteur for } & \text { Freedom } & \text { Expression. } & \text { Available }\end{array}$ https://www.oas.org/en/iachr/expression/showarticle.asp?artID=738\&lID=1

Jones, D.E. (2002). Censorship: A world encyclopedia. London: Fitzroy Deadborn Publishers.

Knightley, P. (1975). The first casualty: The war correspondent as hero, propagandist, and myth maker from the Crimea to Vietnam. London: Deutsch.

Miller, D. (1994). Don't Mention the War: Northern Ireland, propaganda and the media. Londres: Pluto.

Molano, A. (2008). 'Recurso'. El Espectador, 2 May. Available from http://www.elespectador.com/opinion/columnistasdelimpreso/alfredo-molano-bravo/columna-recurso

Monroe E. P. \& Thompson, M. (Eds). (2002). Forging peace: Intervention, human rights and the management of media space. Edinburgh: Edinburgh University Press

Montaña, S., González, V., \& Ariza, C. (2015). Beyond the'sewer': online media forums as shapers of digital public opinion in the framework of Colombian peace talks (2012). Journal of Latin American Communication Research, 5(1), 87-114.

Orwell, G. (1972, 1946). The freedom of the press. In 'Preface' to Animal farm (5 ${ }^{\text {th }}$ ed.). London: The Times Literary Supplement.

Reporters Without Borders (2010). ChuzaDAS: Media targeted by intelligence services. Available from http://www.guardian.co.uk/media/2003/oct/22/pressandpublishing

Reporters Without Borders (2019). Colombia: Violence and self-censorship. Available from https://rsf.org/en/colombia

Roldán, I., Giraldo, D. \& Flórez, M. (2008). Impacto del conflicto colombiano en los periodistas. Revista Colombiana de Psiquiatría, 37(1), 66-80.

Samper, D. (1984). La Prensa en Colombia. Gaceta de C.P.B., 34, May-August Bogotá: El Ancora Editores.

United Nations High Commissioner of Refugees. (2007). Report 2002-2007 on Internal Displacement in Colombia. Available from http://www.acnur.org/crisis/colombia/desplazamiento.htm

Universidad de la Sabana. (2010). Directores de Medios de Comunicación conceptúan sobre la Libertad de prensa, el proceso de paz y el acuerdo por la discreción. Observatorio de Medios: Universidad de la Sabana. Available from http://sabanet.unisabana.edu.co/comunicacion/observatorio2006/Archivo/pag antigua/investigacion.htm

Waisbord, S. (2000). Watchdog journalism in South America: news and accountability. New York: Columbia University Press.

Warburton, N. (2009). Free Speech: A very short introduction. Oxford: Oxford University Press.

Wolfsfeld, G. (2004) The Media and the path to peace. Cambridge: Cambridge University Press.

Wolton, D. (2003). Les journalistes ont-ils encore de pouvoir? Hermès Cognition, Communication, Politique, 35 , 9-21.

\section{Additional Reading}

Arroyave, J., \& Barrios, M. M. (2012). 30 Journalists in Colombia. The Global Journalist in the 21st century, 400.

Barrios, M. M., Estarita, L. M. V., \& Gil, L. M. (2019). When online commentary turns into violence: The role of Twitter in slander against journalists in Colombia. Conflict \& Communication, 18(1).

Beltrán, M. (2008). Freedom of the Press in Canada and Colombia. Desafios, 19, 210-243.

Berastegi, A. Á. (2019). Freedom of the Press and violence in the Basque Country and Colombia. A historical approach to current debates. Revista Latina de Comunicación Social, (74), 33-49.

Brambila, J. A., \& Hughes, S. (2019). Violence Against Journalists. The International Encyclopedia of Journalism Studies, 1-9.

Bushnell, D. (1950). The development of the press in Great Colombia. The Hispanic American Historical Review, 30(4), 432-452.

Prettel, M. G., Jaramillo, L. G., Cabrera, J. A., \& Majul, A. D. Á. (2019). Libertad de prensa y conflicto armado en Colombia: Un análisis desde la autonomía profesional percibida por los periodistas colombianos. Saber, ciencia y libertad, 14(1), 21-34.

Weiss, A. S. (2015). The digital and social media journalist: A comparative analysis of journalists in Argentina, Brazil, Colombia, Mexico, and Peru. International Communication Gazette, 77(1), 74-101.

\section{Key Terms and Definitions}

Arauca: This conglomerate has four broadcast stations: La Voz del CInacuro (affiliated to Caracol Radio), Meridiano 70 (independent), La Voz del Rio Arauca (affiliated to RCN), and Radio DIC (community radio). There are two local media: Sarare estéreo and Tame estéreo, besides the army's radio. Newspapers: El Corredor and Nueva Frontera (RWB, 2010). 
COLPRENSA S.A.: This is a Colombian news agency based on national news, directed by Victor Diusabá and created by an amalgamation of regional newspapers in 1981. These include thirteen of the most important newspapers in the country, such as: El Colombiano (Medellín), Vanguardia Liberal (Bucaramanga), El Universal (Cartagena), La Opinión (Cúcuta), La Patria (Manizales), La Tarde (Pereira), La República (Bogotá), El País (Cali), El Nuevo Día (Ibagué), El Liberal (Popayán), El Meridiano (both Córdoba and Sucre), Hoy Diario del Magdalena, as well as popular newspapers such as La Chiva (Medellin) and Qu'hubo (Cali). This news outlet has obtained a journalism prize. (El Colombiano, 2006). El Colombiano (2010) 'Colprensa, más de 9,000 días conociendo a Colombia' Piñeros, A.

Culture of Silence: This refers to the spectrum that affects media, journalists, and citizens who choose to overlook certain information.

Embedded Journalism: This term refers to reporters who travel to warzone commonly with the American or British military. They stay in the 'Green Zone' where the army lives in war. There is a limitation of movement and censorship (Cockburn, 2010) therefore reporting a distorted view of war.

Threatened Journalists: These are journalists that experienced myriads of threats while on duty. In Colombia some notable threatened journalists include the following: Carmen Rosa Pabón, Lizneira Roncancio, Yineth Pinilla, Hernan Morales, Henry Colmenares, Willian Reyes, José Antonio Zocadagui, Carlos Perez, Emiro Goyeneche, Rodrigo Anila, Narda Guerrero, Angel Maria Leon, Miguel Angel Tojas, Zorayda Aliza, Luis Guedes (International Federation of Journalists, 2003).

\footnotetext{
i Jaime Garzón Forrero (1960-1999) a famous journalist, humourist and peace-negotiator, assassinated by paramilitary Carlos Castano.

ii Embedded journalism refers to reporters who travel to warzone commonly with the American or British military. They stay in the 'Green Zone' where the army lives in war. There is a limitation of movement and censorship (Cockburn, 2010) therefore reporting a distorted view of war.

iii Polemic and critical, Varela was the 52-year-old journalist, owner, and director of Meridiano 70. Murdered on June 28 ${ }^{\text {th }}$, 2002, Noriega directed the news program 'La actualidad informativa' for eight years. He was also a former El Espectador correspondent.
} 